\title{
EDITORIAL
}

\section{Using our voices-and using our science}

\section{Johanna M. Hinman, MPH, MCHES ${ }^{1}$}

${ }^{1}$ Associate Director of Education, Department of Surgery, Emory University School of Medicine and President-Elect, Georgia Public Health Association

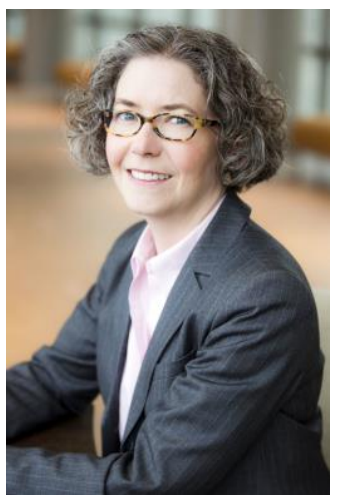

At the close of the 2015 Annual Meeting and Conference of the Georgia Public Health Association (GPHA), President Deborah Riner encouraged the assembly to "use your voice[s]," to be advocates for public health. Indeed, the history of our successes in public health reflects a history of advocacy, of speaking up to make change. Our charge is to use our voices to express our passion for public health or specific public health causes, and to use our voices to promote the best available science.

As Cynthia Hallett, Executive Director of Americans for Nonsmokers' Rights, reminded us in her opening keynote address, successes in reducing tobacco use and exposure in the United States are the results of long and careful advocacy efforts focusing on what science tells us will best protect public health. These efforts have roots in what might have initially seemed an unlikely place - the release of the 1964 Surgeon General's Report on Smoking and Health. The document appears plain and bureaucratic - from its cover, a standard government publication with little to engage the reader. In his foreword, Dr. Luther L. Terry noted, "it has seemed necessary to determine, as precisely as possible, the direction of scientific evidence and to act in accordance with that evidence for the benefit of the people of the United States." Hardly a rousing call to particular action. However, the weight of the evidence that Terry's advisory committee reviewed (some 7,000 scientific studies) ii led them to this statement: "On the basis of prolonged study and evaluation of many lines of converging evidence, the Committee makes the following judgment: Cigarette smoking is a health hazard of sufficient importance in the United States to warrant appropriate remedial action."

Since this simple but powerful statement, the United States has witnessed changes in policy and in social norms, and dramatic reductions in smoking rates and disease. By issuing a report that reviewed scientific evidence and made recommendations grounded in that science, Dr. Terry and his colleagues provided a solid and defensible platform for decades of advocacy that would follow.
Our charge as public health professionals in the $21^{\text {st }}$ century is continue to define the "many lines of converging evidence" for the public health challenges we face and to advocate for the programs and policies to which the evidence guides us. Let us ground our actions in science to advance the public's health.

${ }^{\mathrm{i}}$ U.S. Department of Health, Education, and Welfare. Smoking and Health: Report of the Advisory Committee to the Surgeon General of the Public Health Service. Washington: U.S. Department of Health, Education, and Welfare, Public Health Service, Center for Disease Control, 1964. PHS Publication No. 1103.

ii U.S. Department of Health and Human Services. The Health Consequences of Smoking - 50 Years of Progress: A Report of the Surgeon General. Atlanta, GA: U.S. Department of Health and Human Services, Centers for Disease Control and Prevention, National Center for Chronic Disease Prevention and Health Promotion, Office on Smoking and Health, 2014

\section{JOURNAL OF THE GEORGIA PUBLIC HEALTH ASSOCIATION Editorial Board}

Guest Editor

Selina A. Smith, PhD, MDiv Institute of Public and Preventive Health Georgia Regents University

Founding Editor

McKinley Thomas, EdD Mercer University

Members

Marsha Davis, PhD University of Georgia

Luke Fiedorowicz, PhD

Georgia Department of Public Health D. Stephen Goggans, MD, MPH

Director, East Central Health District Johanna M. Hinman, MPH, MCHES Emory University

Carole C. Jakeway, MPH, BSN, RN

Georgia Department of Public Health

Raymona H. Lawrence, DrPH, MPH, MCHES Georgia Southern University Stephanie Miles-Richardson, DVM PhD Morehouse School of Medicine Karen Minyard, PhD

Georgia State University Olugbenga O. Obasanjo, MD, PhD, MPH, MBA Director, District 4 Public Health

Sara S. Plaspohl, DrPH, CHES, CIM, CIP Armstrong State University Oreta Samples, RVT, MPH, DHSc Ft. Valley State University

Community Representative Merrilea Reeves, MSN, FNP Chairman, Board of Health Spalding County
Student Representative

Ex-Officio Member Georgia State University

Regina Abbott, MPA
Sankan Nyanseor 